\section{Spectrophotometric Titration of Tyrosine Residues of Beef Heart Cytochrome e}

\section{T. FLATMARK}

\section{Department of Medical Chemistry, University of Umea, Umea, Sweden*}

\begin{abstract}
Spectrophotometric titrations of protein tyrosyl groups, which ionize in alkaline solution, may give information about: (1) The total number of tyrosine residues of the protein, (2) the number of "free" and "bound" tyrosyl groups, and (3) the denaturation of the protein in alkaline solution. Since so far cytochrome $\mathrm{c}^{* *}$ has not been subjected to such titrations, the present study was performed.
\end{abstract}

Materials and methods. Beef heart cyt. c was obtained in the native, monomeric form by gel filtration on Sephadex G-75; ${ }^{1}$ the ratio $A_{550 \text { red }} / A_{280 \text { ox }}=1.26(\mathrm{pH} 6.8)$ and the iron content $=0.43(8) \%$. The hemoprotein was isolated in the ferric form by chromatography on Duolite CS-101,2 dialyzed against $2 \mathrm{mM}$ ammonia and centrifuged $(35000 \times g$, $30 \mathrm{~min}, 4^{\circ} \mathrm{C}$ ) before use. The concentration of cyt. c was assayed as previously described;' the millimolar extinction coefficient $\varepsilon\left(\mathrm{cm}^{-1} \times\right.$ $\mathrm{mM}^{-1}$ ) at $550 \mathrm{~m} \mu$ red $=30.53^{1}$ was used. A.g. tyrosine and tryptophan were obtained from Hopkin \& Williams Ltd., England. The concentration of tyrosine was assayed in $10 \mathrm{mM}$ sodium acetate (pH 6.1) by using $\varepsilon\left(\mathrm{cm}^{-1} \times \mathrm{mM}^{-1}\right)$ at $275 \mathrm{~m} \mu=1.23,^{3}$ and the concentration of tryptophan was assayed at pH 7.0 by using $\varepsilon\left(\mathrm{cm}^{-1} \times \mathrm{mM}^{-1}\right)$ at $279 \mathrm{~m} \mu=5.25 .^{3}$ Glycine-KCl-KOH buffers were made by mixing solution $\mathrm{A}(0.30 \mathrm{M} \mathrm{KCl}$ in $0.15 \mathrm{M}$ glycine) and solution $\mathrm{B}(0.15 \mathrm{M} \mathrm{KCl}$ in $0.15 \mathrm{M} \mathrm{KOH}$ ) in various proportions; the pH-measurements were made with glass electrodes (Radiometer, Copenhagen, Denmark, Model $25 \mathrm{SE}$ ) standardized at $\mathrm{pH} \mathbf{7 . 0 2}$ and 9.18 with standard buffers. Difference spectra were obtained by a Beckman DK-2A recording spectrophotometer, but otherwise

* Present address: Institute for Thrombosis Research, University Hospital (Rikshospitalet), Oslo, Norway.

** The following abbreviation will be used: Cyt. $\mathrm{c}=$ cytochrome $\mathrm{c}$.

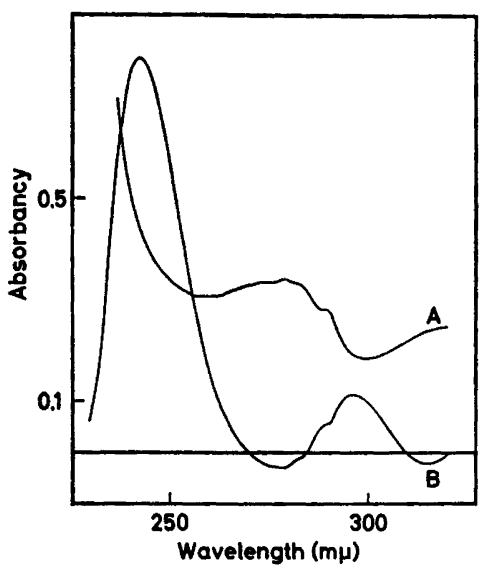

Fig. 1. Ultraviolet absorption spectrum of

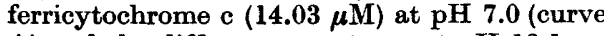
A) and the difference spectrum at $\mathrm{pH} 13.1 \mathrm{vs}$. pH 7.0 (curve B). Curve B has not the form of the spectrum obtained immediately upon bringing the enzyme solution to $\mathrm{pH}$ 13.1; the absorbancy first increased rapidly to about $94 \%$ of the height of the curve, during the first minute, then rose within $10 \mathrm{~min}$ to its final value ( $c f$. Fig. 2 , curve A). $25^{\circ} \mathrm{C}$.

a Beckman DU spectrophotometer was used. The cell compartment of both instruments was maintained at $25^{\circ} \mathrm{C}$ by water circulation.

Results and discussion. The ultraviolet absorption spectrum of ferri-cyt. $\mathrm{c}$ at $\mathrm{pH}$ 7.0 is shown in Fig. 1, curve A; the main peak is at about $279 \mathrm{~m} \mu$. The difference spectrum of ferri-cyt. c at $\mathrm{pH} 13.1 \mathrm{vs}$. $\mathrm{pH}$ 7.0 (Fig. 1, curve B) shows a high peak at about $243 \mathrm{~m} \mu$ and a low peak at about $296 \mathrm{~m} \mu$, in good agreement with that obtained for tyrosine alone, i.e. at $241 \mathrm{~m} \mu$ and $294 \mathrm{~m} \mu$, respectively. For the assay of the ionization of tyrosyl groups of cyt. c as a function of $\mathrm{pH}$, the difference in absorbancy at $243 \mathrm{~m} \mu$ was preferred," because heme absorption overlaps the $296 \mathrm{~m} \mu$ phenolate peak. ${ }^{5}$ Furthermore, the peak at $243 \mathrm{~m} \mu$ seems to be especially useful in the case of cyt. c since this hemoprotein contains no free sulphydryl groups, ${ }^{6-8}$ the ionization of which also gives an increase in absorbancy at $243 \mathrm{~m} \mu ;^{5}$ the two cysteine residues of the protein moiety are linked to the heme by thioether bonds. ${ }^{9-11}$

Acta Chem. Scand. 18 (1964) No. 7 


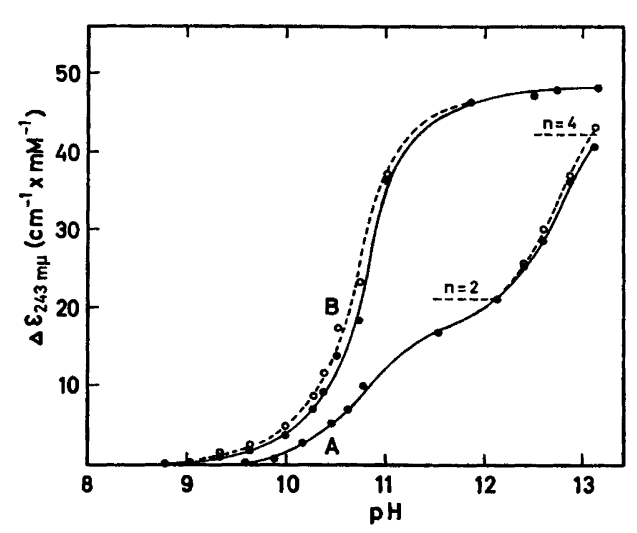

Fig. 2. Spectrophotometric titration curves for the tyrosyl groups of ferricytochrome c. The lower curves (A) were obtained in glycineKCl-KOH buffer, $\mu \approx 0.3$, and the upper curves (B) in the same buffer, but with urea added to a final concentration of $8 \mathrm{M}$. The solid and dotted lines indicate the values obtained at 1 and $10 \mathrm{~min}$ after the addition of cytochrome $c$ to the buffer solution, respectively. $25^{\circ} \mathrm{C} . n=$ number of tyrosyl groups titrated/molecule cytochrome c, as calculated from the value of $\Delta \varepsilon_{\max }$ for ionization of free tyrosine. For details see text.

Spectrophotometric titration of tyrosine at $241 \mathrm{~m} \mu$ in the $\mathrm{pH}$ range $8-13.1$ gave the value of $\Delta \varepsilon_{\max }\left(\mathrm{cm}^{-1} \times \mathrm{mM}^{-1}\right)=10.53$ which will be used for the approximate calculation of the number of titratable tyrosine residues in cyt. c.

Fig. 2, curve A shows that the spectrophotometric titration of tyrosyl groups of ferri-cyt. $c$ proceeded in two stages. In the first stage, from $\mathrm{pH} 9.4$ to 12.2 , the ionization was an immediate reaction, and the curve was a typical (S-shaped) titration curve with an apparent $\mathrm{p} K$ of 10.8 ; the total change in absorbancy corresponded to the ionization of two tyrosine residues. In the second stage, from $\mathrm{pH} 12.2$ to 13.1 , a higher value of $\Delta A_{243} / \Delta \mathrm{pH}$ was obtained, and the absorbancy showed a slight increase with time. A time-dependent increase in light absorption, which can be attributed to ionization of tyrosyl groups, is generally interpreted as a result of denaturation of the protein. ${ }^{12}$ Thus, the critical $\mathrm{pH}$ for denaturation of cyt. c in alkaline solution at $\mu \approx 0.3$ appears to be at approximately 12.2. This result is in good agreement with earlier observations that cyt. c is perfectly stable from $\mathrm{pH}$ 1.6 to 12.3 as determined by its catalytic activity in the succinate oxidase system. ${ }^{13}$ It is noteworthy that even at $\mathrm{pH} 13.1$ the end point of the titration is not reached.

Spectrophotometric titration at maximum ionization of tyrosyl groups of ferricyt. c was performed in a denaturing solvent ${ }^{14}$ (Fig. 2, curve B). Thus, in the presence of $8 \mathrm{M}$ urea the ionization started at about $\mathrm{pH} 8.8$, and the resemblance to a normal (S-shaped) titration curve with an apparent $\mathrm{p} K$ of 10.8 , was observed. This effect of urea on cyt. c is in good agreement with that observed on ribonuclease. ${ }^{14}$ Based on the value of $\Delta \varepsilon_{\max }$ for free tyrosine given above, 4.6 tyrosine residues were calculated in beef heart cyt. c. The interpretation of this result must, however, be made with some reserve. Thus, indole groups of tryptophan absorb in the same region of the spectrum as tyrosine phenolic groups, and tryptophyl perturbation may influence the spectrophotometric titration of protein tyrosine residues. ${ }^{5,12}$ From the difference spectrum of free tryptophan at $\mathrm{pH} 13.1$ vs. $\mathrm{pH} 7.0$ the value of $\Delta \varepsilon\left(\mathrm{cm}^{-1} \times \mathrm{mM}^{-1}\right)$ at $243 \mathrm{~m} \mu$ was calculated to be 0.05 , but since cyt. c contains only one tryptophan residue, ${ }^{6}$ the correction to be made for this perturbation will be small. However, there are spectral shifts, both for indole and phenolic groups, which are not related to hydrogen ion dissociation,,$^{5,12}$ and from titration studies on ribonuclease, ${ }^{15}$ as well as on human and horse hemoglobin and globin ${ }^{4}$, it is known that the values of $\Delta \varepsilon_{\max }$ per tyrosine residue of these proteins are higher than that of free tyrosine. According to Hermans, ${ }^{4}$ the $\Delta \varepsilon_{\max }$ values differ by $20 \%$ from protein to protein. Thus, if the calculation of the number of tyrosine residues in proteins is based on the value of $\Delta \varepsilon_{\max }$ for the ionization of free tyrosine, too high values will often be obtained. The number of tyrosine residues of beef heart cyt. c has previously been calculated from determinations on protein hydrolysates and stated to be four, but there are considerable variations in the published values. ${ }^{6,16-19}$ In view of the source of errors discussed above, the result obtained in the present study seems to be in reasonable agreement with four tyrosine residues, and from the titration curve (A) given in Fig. 2 these residues can be divided into two types as previously 
reported for ribonuclease..$^{15,20}$ Two tyrosyl groups are "free" and ionize in a normal way and two are "bound" and ionize much less readily. In view of this fact it is interesting to mention the results of some iodination experiments on horse heart cyt. c, which also contains four tyrosine residues. ${ }^{21}$ Thus, Ishikura et al. ${ }^{22}$ found that 4 iodine atoms were readily (within $1 \mathrm{~min}$ ) incorporated into the hemoprotein at $\mathrm{pH} 7.0$, corresponding to the iodination of two tyrosine residues, which resulted in a complete loss of its electron transferring activity. The iodination of the other residues was found to proceed at a much slower rate.

Acknowledgement. The author wishes to express his thanks to Professor K. G. Paul for his interest and advice and for his kind hospitality. Thanks are due to Med. kand. A. Carlström for valuable discussions. A travel sholarship from Aktieselskapet Freya Chocolade Fabriks Medicinske Fond is gratefully acknowledged.

1. Flatmark, T. Acta Chem. Scand. 18 (1964) 1517.

2. Flatmark, T. Acta Chem. Scand. 18 (1964) 1656.

3. Fromageot, C. and Schnek, G. Biochim. Biophys. Acta 6 (1950) 113.

4. Hermans, J., Jr. Biochemistry 1 (1962) 193.

5. Wetlaufer, D. B. Advan. Protein Chem 17 (1962) 303.

6. Theorell, H. and Åkeson, A. J. Am. Chem. Soc. 63 (1941) 1804.

7. Åkeson, A. Acta Physiol. Scand. 4 (1942) 362.

8. Paléus, S. Acta Chem. Scand. 9 (1955) 335.

9. Theorell, H. Biochem. Z. 298 (1938) 242.

10. Theorell, H. Enzymologia 6 (1939) 88.

11. Paul, K. G. Acta Chem. Scand. 5 (1951) 389.

12. Tanford, C. Advan. Protein Chem. 17 (1962) 69.

13. Paul, K. G. Acta Chem. Scand. 2 (1948) 430.

14. Blumenfeld, O. O. and Levy, M. Arch. Biochem. Biophys. 76 (1958) 97.

15. Tanford, C., Hauenstein, J. D. and Rands, D. G. J. Am. Chem. Soc. 77 (1956) 6409.

16. Ehrenberg, A. and Theorell, H. Acta Chem. Scand. 9 (1955) 1193.

17. Takahashi, K., Titani, K. and Minakami, S. J. Biochem. (Tokyo) 46 (1959) 1323.

18. Paléus, S. Acta Chem. Scand. 14 (1960) 1743.

19. Yasunobu, K. T., Nakashima, T., Higa, H., Matsubara, $\mathrm{H}$, and Benson, A. Biochim. Biophys. Acta 78 (1963) 791 .
20. Shugar, D. Biochem. J. 52 (1952) 142.

21. Margoliash, E., Kimmel, J. R., Hill, R. L. and Schmidt, W. R. J. Biol. Chem. 237 (1962) 2148.

22. Ishikura, H., Takahashi, K., Titani, K. and Minakami, S. J. Biochem. (Tokyo) 46 (1959) 719 .

Received August 26, 1964.

\section{On the Crystal Structure of MoAs,}

\section{PER JENSEN and ARNE KJEKSHUS}

\section{Kjemisk Institutt A, Universitetet i Oslo, Blindern, Oslo 3, Norway}

Tn a recent study of molybdenum Iarsenides, the existence of a previously unknown phase with composition $\mathrm{MoAs}_{2}$ has been established.

Samples were prepared from $99.9 \%$ pure molybdenum (L. Light \& Co., Ltd.) and $99.999 \%$ pure metallic arsenic (Johnson, Matthey \& Co., Ltd.). Samples with composition $60.00,65.52,66.67,67.74$, and 75.00 atomic \% As were made by heating accurately weighed quantities of molybdenum and arsenic in evacuated and sealed silica tubes. The samples were heated at $600^{\circ} \mathrm{C}$ for 5 days, and quenching in ice water as well as slow-cooling was used.

All samples were crushed and X-ray photographs taken in a Guinier focusing camera of $80 \mathrm{~mm}$ diameter with strictly monochromatized $\mathrm{CuK} \alpha_{1}$-radiation. For the calculation of lattice constants potassium chloride (Analar, The British Drug Houses, Ltd., $a=6.2919 \AA^{1}$ ) was added as an internal standard. Lattice constants are expressed in Ångström units on the basis of $\lambda\left(\mathrm{CuK} \alpha_{1}\right)=1.54050 \AA$. Densities were determined by the pycno. metric method at $25^{\circ} \mathrm{C}$ with kerosene as displacement liquid.

In the molybdenum-arsenic system three intermediate phases have been identified. Two of the phases with approximate compositions $\mathrm{MoAs}_{\mathbf{0 . 8}}$ and $\mathrm{MoAs}_{1.4}$ will be the subject of a fortheoming paper; ${ }^{2}$ and only the structural properties of the third phase, $\mathrm{MoAs}_{2}$, will be discussed here. Guinier photographs of this phase, cf. Table 1, could be indexed on the basis of a monoclinic unit cell with dimensions: 